\title{
Membaca Bakat dengan Aplikasi Talents Mapping untuk Tenaga Pendidik dan Kependidikan SMK Catur Global Kota Bekasi
}

\author{
Prio Kustanto ${ }^{1}$, Andry Fadjriya ${ }^{1}$, Rakhmat Purnomo ${ }^{1, *}$ \\ ${ }^{1}$ Fakultas IImu Komputer; Universitas Bhayangkara Jakarta Raya; Jl. Raya Perjuangan \\ No.81, Marga Mulya, Bekasi Utara, Jawa Barat 17142. Telp: +622188955882, \\ +6221889955883; e-mail: pkustanto@dsn.ubharajaya.ac.id, andri.fajia@dsn.ubharajaya.ac.id, \\ rakhmat.purnomo@dsn.ubharajaya.ac.id \\ * Korespondensi: e-mail: pkustanto@dsn.ubharajaya.ac.id
}

Submitted: 05/01/2021; Revised: 12/01/2021; Accepted: 19/01/2021; Published: 29/01/2021

\begin{abstract}
Measurement/reading of the talents of each personal educator(teacher) and education personnel need to be done. Among the applications that can be used to take such measurements is to use the Talents Mapping application. Measurement with Talents Mapping aims to analyze the suitability of talent with the field of work, and provide recommendations of the results of reading the talent on the leadership/management. Before the measurement is done, it is necessary to explain talents mapping. This is necessary to provide initial insights and knowledge about Talents Mapping, and the measurement methods to be performed. After the measurement results are obtained, discussions can be made on the results of these measurements. The results of measuring/reading the talents of each personal educator and education personnel with the Talents Mapping Application is expected to help determine the suitability of talent with the field of work pursued by educators and education personnel, as well as provide recommendations of the results of reading the talent to the management/school leadership.
\end{abstract}

Keywords: Talents Mapping, Talent, Educators, Educational personnel, Strength Topology

\begin{abstract}
Abstrak
Pengukuran/pembacaan bakat tiap personal tenaga pendidik(guru) dan tenaga kependidikan perlu dilakukan. Diantara aplikasi yang bisa digunakan untuk melakukan pengukuran tersebut adalah dengan menggunakan aplikasi Talents Mapping. Pengukuran dengan Talents Mapping bertujuan untuk menganalisa kesesuaian bakat dengan bidang kerja, dan memberikan rekomendasi hasil pembacaan bakat tersebut pada pihak pimpinan/manajemen. Sebelum dilakukan pengukuran, perlu dilakukan penjelasan tentang Talents Mapping. Hal tersebut diperlukan untuk memberikan wawasan dan pengetahuan awal tentang Talents Mapping, dan metode pengukuran yang akan dilakukan. Setelah hasil pengukuran didapatkan maka bisa dilakukan diskusi terhadap hasil pengukuran tersebut. Hasil dari pengukuran/pembacaan bakat tiap personal tenaga pendidik dan tenaga kependidikan dengan Aplikasi Talents Mapping diharapkan dapat membantu mengetahui kesesuaian bakat dengan bidang kerja yang digeluti oleh tenaga pendidik dan kependidikan, serta memberikan rekomendasi hasil pembacaan bakat tersebut pada pihak manajemen/pimpinan sekolah.
\end{abstract}

Kata kunci: Talents Mapping, Bakat, Tenaga Pendidik, Tenaga Kependidikan, Strength Topology 


\section{Pendahuluan}

Talents Mapping menurut Abah Rama Royani, merupakan cara asesmen atau menilai dan menggali bakat (karateristik produktif) dan potensi kekuatan kita dengan tampilan hasil yang lengkap, mudah dipahami dan menarik. Cara ini bisa mengidentifikasi potensi kekuatan individu yang mencakup pengukuran dan pernyataan kekuatan diri (Personal Strengths Statement) (Febrida, 2014). Talents Mapping juga dapat membantu menemukan bakat terpendam, dan mengarahkan orang agar tidak fokus pada kelemahannya saja (Karyaone, 2020).

Banyak organisasi yang mengembangkan karyawannya melalui Deficit Approach, yaitu pendekatan mencari kelemahan seseorang dan kemudian berusaha memperbaiki kelemahan tersebut agar menjadi kompeten, sehingga harapannya yang bersangkutan dapat memberikan kinerja yang diharapkan. Dalam beberapa hal pendekatan dengan cara ini cukup baik akan tetapi dalam banyak hal dirasa kurang tepat dan tidak berdampak terhadap peningkatan kinerja organisasi.

Dengan Talents Mapping ini, diharapkan orang tak lagi fokus dengan kelemahannya dan cara mengatasinya, melainkan lebih melihat kepada kekuatan yang dimiliki dalam diri masing-masing. Diantara cara untuk untuk menemukan potensi bakat dan kekuatan seseorang adalah dengan Strength Typology (ST-30). Mengukur potensi bakat seseorang dengan ST-30 dianggap sebagai cara yang paling cepat dalam menemukan diri. $S T-30$ juga bisa menampilkan hasil pengukuran yang merupakan gambaran kemampuan/kompetensi dan minat terhadap peran. ST-30 memiliki tiga puluh tipologi manusia yang terkait dengan kekuatan yang produktif. Selain itu dapat juga digunakan sebagai personal brand atau self-awareness bagi seseorang (Febrida, 2014).

Salah satu Aplikasi yang dikembangkan oleh Abah Rama Royani untuk membaca bakat dengan metode kuisioner adalah ST-30. Aplikasi tersebut dapat diakses dalam situs https://temubakat.com/id/. Ada dua macam aplikasi kuisioner dalam aplikasi tersebut, yaitu ST30 yang yang berisi kuisioner ST-30 yang sederhana dan dapat dilakukan gratis, dan satu lagi adalah Talents Mapping Assesment dengan kuisioner yang jauh lebih lengkap dengan 170 pertanyaan seputar Talents Mapping dan 114 pertanyaan seputar Personal Strength (Fajria, 2019).

Talents Mapping Assesment (TMA) umumnya sudah bisa dilakukan dengan baik oleh anak usia SMA. Walaupun ada beberapa kasus anak usia SMP dan SD dapat mengisi Talents Mapping Assesment dengan baik. Oleh karenanya dapat disimpulkan bahwa Talents Mapping Assesment lebih tepat untuk dapat digunakan membaca bakat seseorang dengan usia SMA keatas dengan baik (Fajria \& Dewi, 2019). Dengan asesmen Talents Mapping, peserta akan menerima urutan bakat dari yang paling dominan [urutan pertama] sampai yang paling tidak dominan (urutan terakhir) dan dengan mengetahui 7 sd 10 bakat dominannya (TDC Indonesia, 2011). 
Berdasarkan pengalaman yang dirasakan setelah mengikuti tes Talents Mapping, peserta tes yang diantaranya guru menyimpulkan bahwa tingkat akurasinya mencapai 90 hingga 94 persen. Sehingga dengan mengetahui potensi diri, maka seseorang akan berusaha untuk memaksimalkan potensi yang ada dan bisa lebih bermanfaat bagi lingkungannya. Talents mapping bermafaat untuk semua orang dan dari segala kalangan. Tidak hanya bermanfaat bagi remaja, namun juga mereka yang mau pensiun, bahkan para guru. Guru merupakan variable yang strategis di dalam sistem pendidikan Indonesia. Dengan guru mengikuti dan memahami talents mapping, mereka bisa memiliki pengalaman untuk mengevaluasi dirinya dan memberikan assessment untuk mengarahkan siswanya. Dengan Talents Mapping, guru bisa mengevaluasi karir dan mempersiapkan karir bagi yang akan pensiun. Sementara bagi guru muda adalah untuk pengembangan karir lebih lanjut (Fauzan, 2019).

Pada beberapa perusahaan, atas dasar pertimbangan bahwa karyawan merupakan asset perusahaan yang paling penting, maka ada yang menyelenggarakan pelatihan pengembangan bakat (Talent Development) yang difokuskan untuk menemukan tingkat pengaruh pada bakat menuju tingkat produktivitas karyawan dan berguna dalam pelaksanaan talenta pengembangan di perusahaan (Ningrum \& Welly, 2012).

SMK Catur Global merupakan salah satu sekolah menengah kejuruan swasta yang berada di Kota Bekasi, provinsi Jawa Barat. SMK Catur Global memiliki visi untuk mewujudkan SMK yang mandiri dan berkualitas tinggi, peserta didik yang berkarakter mulia, dan menghasilkan tamatan yang kompeten sesuai bidangnya. Sedangkan misi dari SMK Catur Global Kota Bekasi adalah 1) Menyelenggarakan pendidikan yang berbasis teknologi utuk menghasilkan luliusan yang berkulitas yang memiliki daya saing yang tinggi dimasyarakat. 2) Mengandakan pengembangan dan penerapan ilmu pengetahuaan teknologi melalui pratikum dan magang di dunia industri secara langsung. 3) Melaksanakan kegiatan intra dan ekstrakurikuler untuk menunjang prestasi siswa untuk mencapai prestasi yang terbaik.

SMK Catur Global yang sudah mulai beroperasional sejak tahun 2009 memiliki tenaga pengajar dan tenaga kependidikan sekitar 30 orang. Dalam melakukan penempatan/penugasan Sumber Daya Manusia (SDM) belum pernah dilakukan pengukuran atau mempertimbangkan minat/bakat yang dimiliki oleh masing-masing personel, sehingga kemungkinan kekeliruan dalam penempatan tugas mungkin saja terjadi.

Sebagai bagian dari mitra Masyarakat dari Universitas Bhayangkara Jakarta Raya, maka melalui tim dosen program studi Informatika membuat program pelatihan membaca bakat dengan aplikasi Talents Mapping untuk memberikan wawasan tambahan terkait konsep bakat dan minat, serta bagaimana cara mengukur dan membaca bakat tersebut dengan menggunakan aplikasi yang sudah ada dan mudah difahami. Program pelatihan tersebut dikemas dalam program Pengabdian kepada Masyarakat (PkM) dengan tema "Membaca Bakat dengan Aplikasi Talents Mapping untuk Tenaga Pendidik dan Kependidikan SMK Catur Global Kota Bekasi". 
Setelah mengikuti pelatihan membaca bakat dengan aplikasi Talents Mapping diharapkan para guru dan tenaga kempandidikan SMK Catur Global bisa lebih mengenal diri sendiri, sekaligus dalam tugasnya sebagai pendidik, semoga dapat mengetahui kekuatan dirinya dan kekutan anak didiknya untuk dapat dimaksimalkan.

\section{Metode Pelaksanaan}

Pelatihan Membaca Bakat dengan Aplikasi Talents Mapping untuk tenaga pendidik dan kependidikan pada SMK Catur Global Kota Bekasi dilaksananan dengan metode Strength Typology (ST-30). Ada empat tahapan yang dilakukan, yaitu 1) tes awal (pre test), 2) penyampaian materi mengenai konsep bakat \& minat, 3) pengisian kuisioner/tes bakat (talents mapping) dengan strength typology (st-30), 4) Membaca hasil tes bakat dan diskusi hasil tes personal, 5) tes akhir (post-test).

Tahap tes awal (pre-test) sebelum rangkaian pelatihan dimulai, dilakukan tes awal(pretest) kepada peserta. Pada tahapan pre-test, peserta diminta untuk mengisi pertanyaan yang sudah disiapkan secara online dalam Google Form (Gubuk Pintar, 2020). Hasil jawaban peserta dijadikan data awal untuk melihat pengetahuan peserta, termasuk nantinya adalah bagaimana progress pemahaman dan kesan peserta setelah mengikuti pelatihan.

Penyampaian materi mengenai konsep bakat \& minat pada tahapan penyampain materi konsep bakat, dijelaskan secara lengkap terkait konsep bakat dan minat, cara mengenal bakat, sampai dengan bagaimana membaca dan menyimpulkan bakat seseorang dengan indikatorindikator bakat yang dimilikinya.

Pengisian kuisioner/tes bakat (Talents Mapping) dengan Strength Typology (ST-30), pada tahapan pengisian kuesioner/tes bakat dilakukan oleh peserta secara online dengan menggunakan personal komputer, laptop, atau dengan menggunakan handphone masingmasing. Setiap peserta mengakses soal tes bakat pada situs https://temubakat.com/id/. Setiap peserta diwajibkan mengisi semua pertanyaan yang diberikan sesuai petunjuk yang diberikan.

Membaca hasil tes bakat dan diskusi hasil tes personal, pada tahapan membaca hasil tes bakat, peserta diminta membaca langsung dilayar output dari aplikasi temubakat yang telah diisi. File hasil berformat pdf yang bisa didownload dan diprint oleh peserta. File tersebut berisi gambar atau grafik Strength Typology berikut penjelasannya. Cara membaca dan diskusi dibimbing langsung oleh pemateri.

Tahap akhir tes akhir (post-test) dilaksananakan setelah semuaa rangkaian pelatihan berakhir. Pada tahapan tes akhir(pos-test), peserta diminta untuk mengisi kembali pertanyaan yang sudah disiapkan secara online dalam Google Form. Hasil jawaban peserta dijadikan data bahasan untuk mengevaluasi bagaimana progress pemahaman dan kesan peserta setelah mengikuti pelatihan. 


\section{Hasil dan Pembahasan}

Acara pelatihan Membaca Bakat dengan Aplikasi Talents Mapping untuk tenaga pendidik dan kependidikan pada SMK Catur Global Kota Bekasi diawali dengan kata pembuka oleh bapak Prio Kustanto, S.T., M.Kom. sekaligus sebagai pemandu acara pelatihan. Kemudian dilanjutkan dengan sambutan dari perwakilan tim dosen program studi Informatika yaitu bapak Rakhmat Purnomo, S.Pd., S.Kom., M.Kom. Dalam sambutannya, beliau menjelaskan bahwa program pelatihan membaca bakat dengan aplikasi Talents Mapping untuk tenaga pendidik dan kependidikan pada SMK Catur Global Kota Bekasi merupakan salah satu bentuk implementasi kerjasama antara Universitas Bhayangkara Jakarta Raya dengan SMK Catur Global Kota Bekasi.

Secara resmi acara pelatihan dibuka oleh ketua Yayasan Catur Global, yaitu bapak H. Riadi, M.Pd, dengan diawali sambutan yang mewakili pihak sekolah. Pada sambutannya, ketua yayasan juga didampingi oleh kepala sekolah SMK Catur Global Bapak Suhanda, S.Ag. Dalam sambutannya beliau menyambut baik kegiatan pelatihan sebagai bentuk pengabdian masyarakat yang dilakukan oleh dosen-dosen program studi Informatika Universitas Bhayangkara Jakarta Raya.

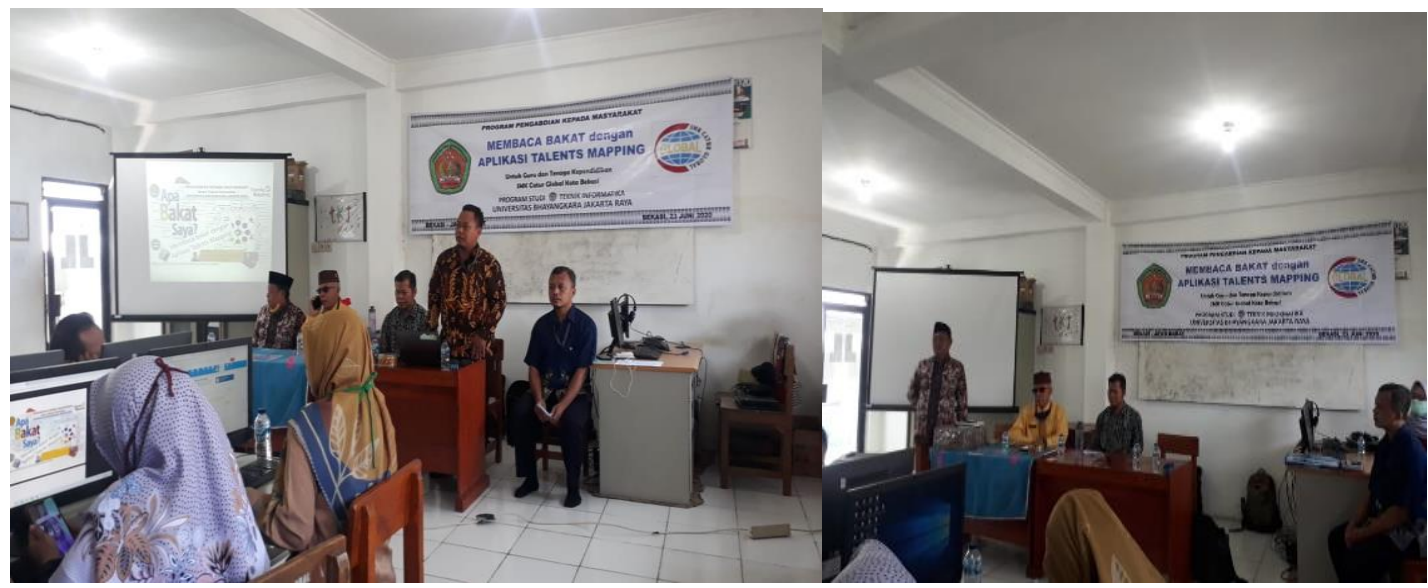

Sumber: Hasil Pelaksanaan (2020)

Gambar 1. Pembukaan Kegiatan

Pelaksanaan program PkM di SMK Catur Global dengan tema Membaca Bakat dengan Aplikasi Talents Mapping untuk Tenaga Pendidik dan Kependidikan pada SMK Catur Global Kota Bekasi dapat digambarkan sebagai berikut:

\subsection{Tes Awal (pre-test)}

pelatihan dimulai dengan tes awal(pre-test) kepada peserta. Para peserta diminta untuk mengisi pertanyaan yang sudah disiapkan secara online dalam Googleform. Hasil jawaban peserta dijadikan data awal untuk melihat pengetahuan peserta, termasuk nantinya adalah bagaimana progress pemahaman dan kesan peserta setelah mengikuti pelatihan.

Dari kuisioner awal, terdapat lima belas peserta yang telah melakukan pre-test. Data yang didapat menurut persepsi peserta, muncul 26 sifat dominan yang dimiliki, dengan sifat 
"baik" sebagai sifat terbanyak yang dipilih oleh peserta. Gambaran data dapat dilihat seperti pada Gambar 2 berikut;

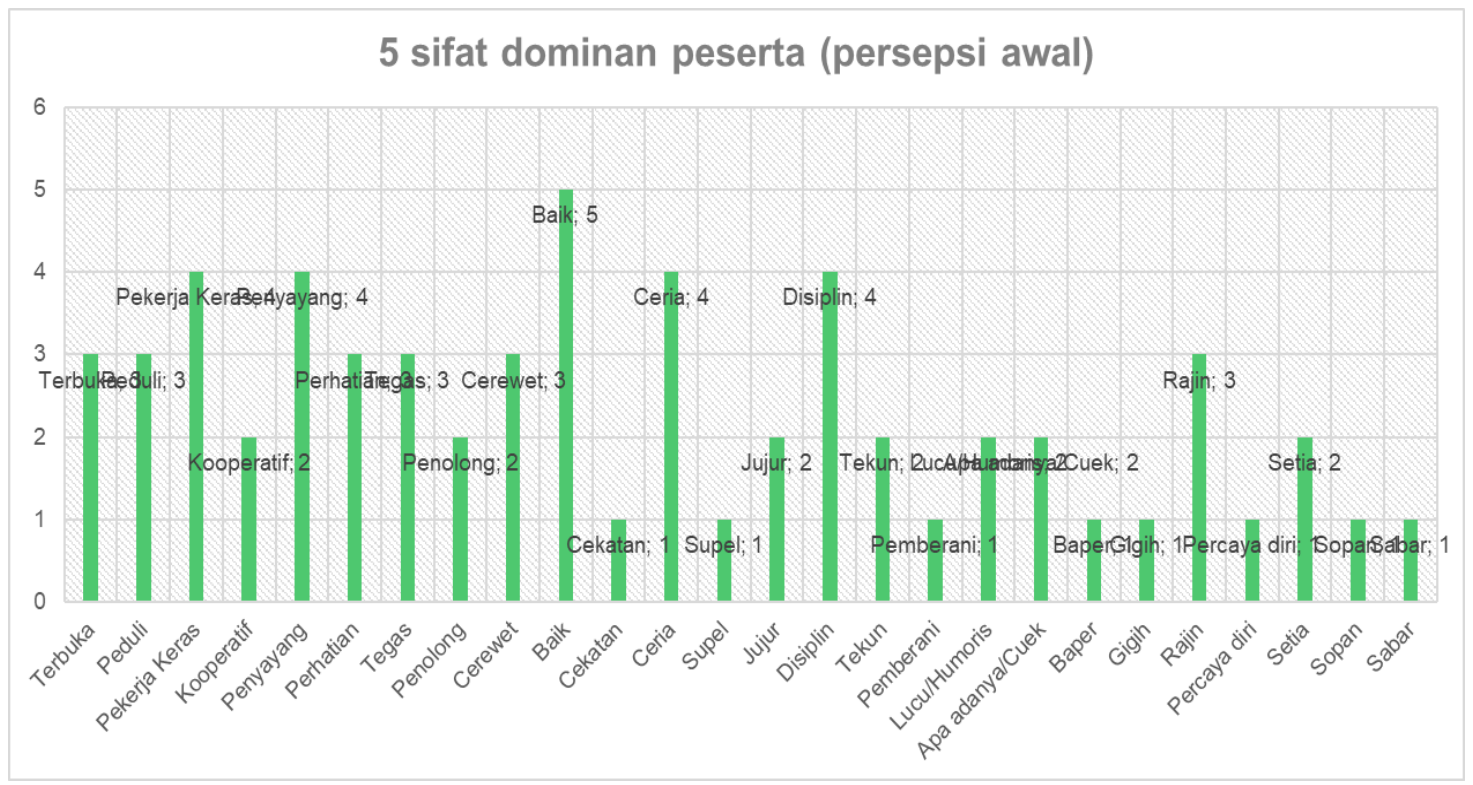

Sumber: Hasil Pelaksanaan (2020)

Gambar 2. Sifat Dominan Persepsi Awal Peserta

Terkait dengan pertanyaan kesesuaian karier yang dijalani selama ini dengan bakat yang dimiliki, sejumlah 14(empat belas) peserta menjawab bahwa karir yang dijalani selama ini sudah cocok(sesuai) dengan bakat yang dimilikinya. Sedangkan 1(satu) peserta menjawab belum cocok. Grafik kesesuaian bakat tersebut seperti yang terlihat pada Gambar.3 berikut;

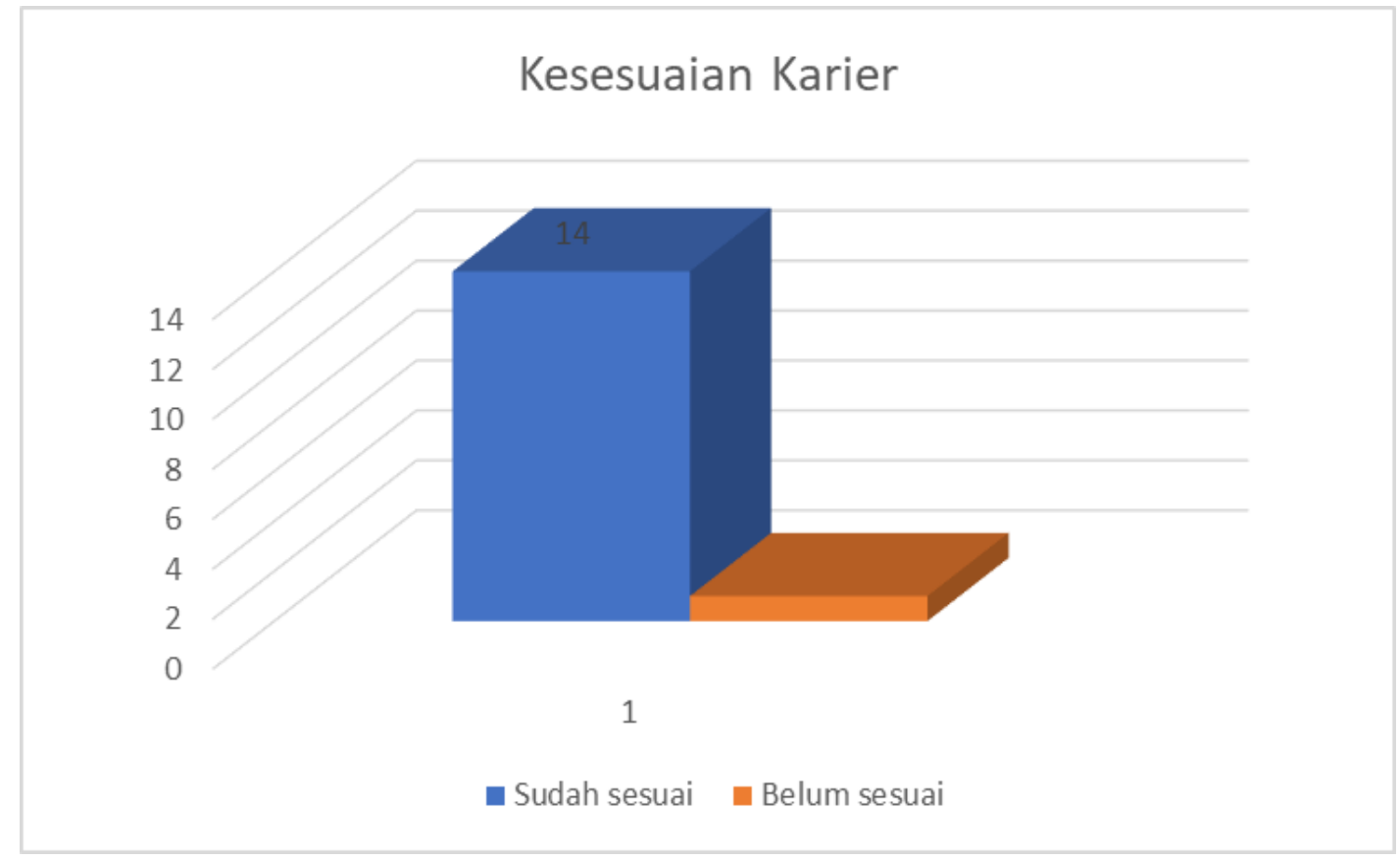

Sumber: Hasil Pelaksanaan (2020)

Gambar 3. Kesesuaian Karier Dan Bakat (Pre-Test) 
Pada Gambar 3 terlihat bahwa peserta yang menjawab bahwa antara karier yang dijalani saat ini dengan bakat yang dimilikinya sudah sesuai/cocok adalah sejumlah 16 peserta atau sekitar $84,21 \%$. Sedangkan yang menjawab Belum sesuai, hamper sesuai, dan sangat sesuai, masing-masing berjumlah 1 orang atau sekitar $5,26 \%$.

Sebagai catatan awal, diketahui bahwa respon peserta dalam pengisian kuisioner awal (pre-test) mencapai $66,67 \%$ atau sekitar 16 peserta dari total peserta yang hadir dan mengisi daftar hadir yaitu 24 peserta.

\subsection{Penyampaian Materi Konsep Bakat \& Minat}

Pada tahapan penyampain materi konsep bakat, dijelaskan secara lengkap oleh Bapak Andri Fajria, S.T., M.T.I., terkait konsep bakat dan minat, cara mengenal bakat, sampai dengan bagaimana membaca dan menyimpulkan bakat seseorang dengan indikator-indikator bakat yang dimilikinya.

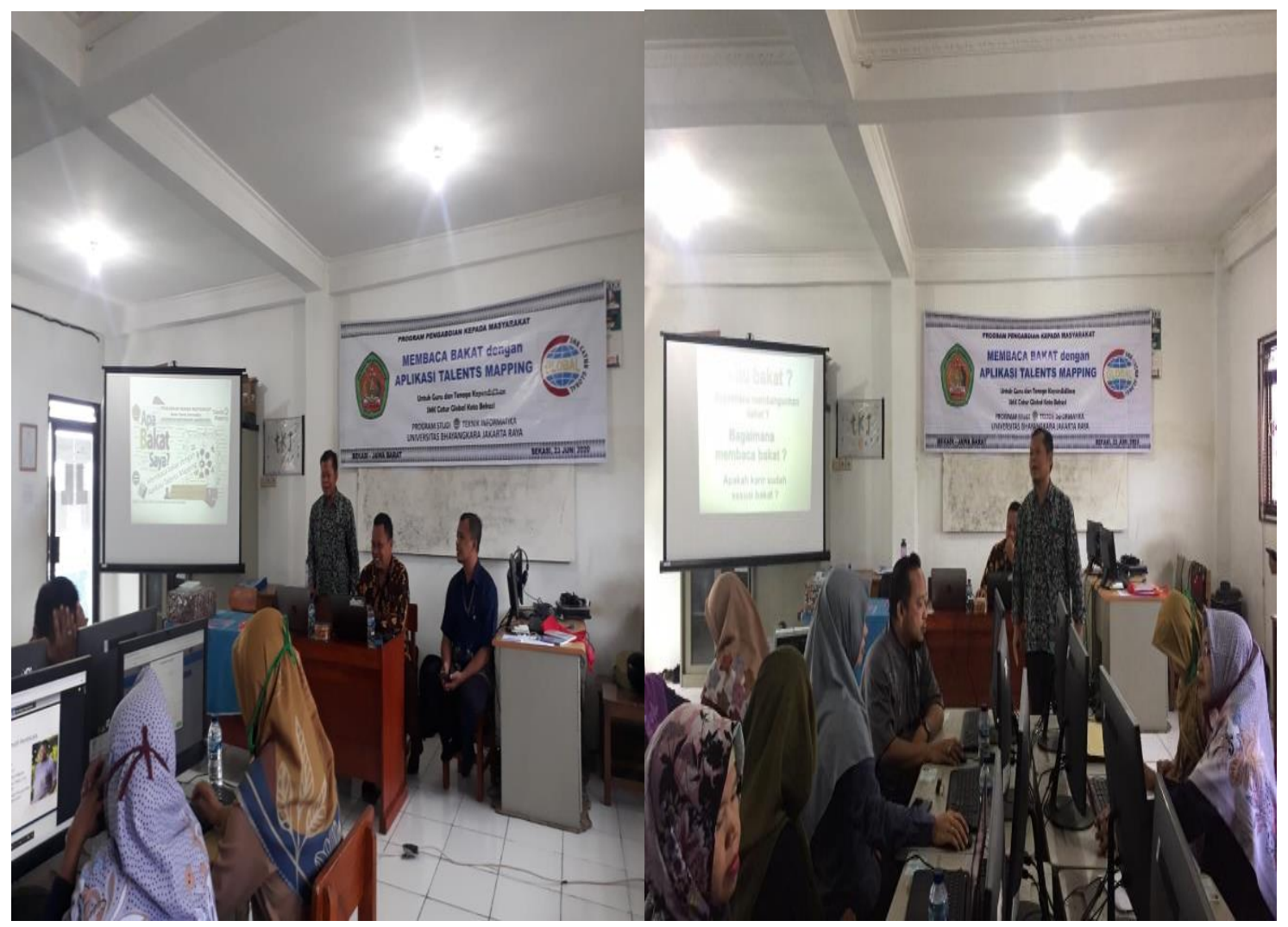

Sumber: Hasil Pelaksanaan (2020)

Gambar 4. Penyampaian Materi Konsep Bakat \& Minat

Para peserta menyimak dengan seksama materi yang dipaparkan dengan tema konsep bakat dan minat, serta bagaimana melakukan assesmen terhadap bakat yang dimiliki seseorang baik pada usia dini, anak-anak, remaja, dampai dengan usia dewasa. Metode apa yang cocok digunakan untuk asesmen pada berbagai tingkatan usia tersebut.

\subsection{Pengisisan kuisioner/tes bakat (Talents Mapping) dengan Strength Typology (ST-30)}

Pengisian materi kuesioner/tes bakat dilakukan oleh masing-masing peserta dengan menggunakan personal komputer yang tersedia di laboratorium komputer SMK Catur Global 
atau laptop yang dibawa peserta, dan bisa juga dengan menggunakan handphone. Setiap peserta mengakses soal tes bakat pada situs https://temubakat.com/id/. Setiap peserta diwajibkan mengisi semua pertanyaan yang diberikan sesuai petunjuk yang diberikan.

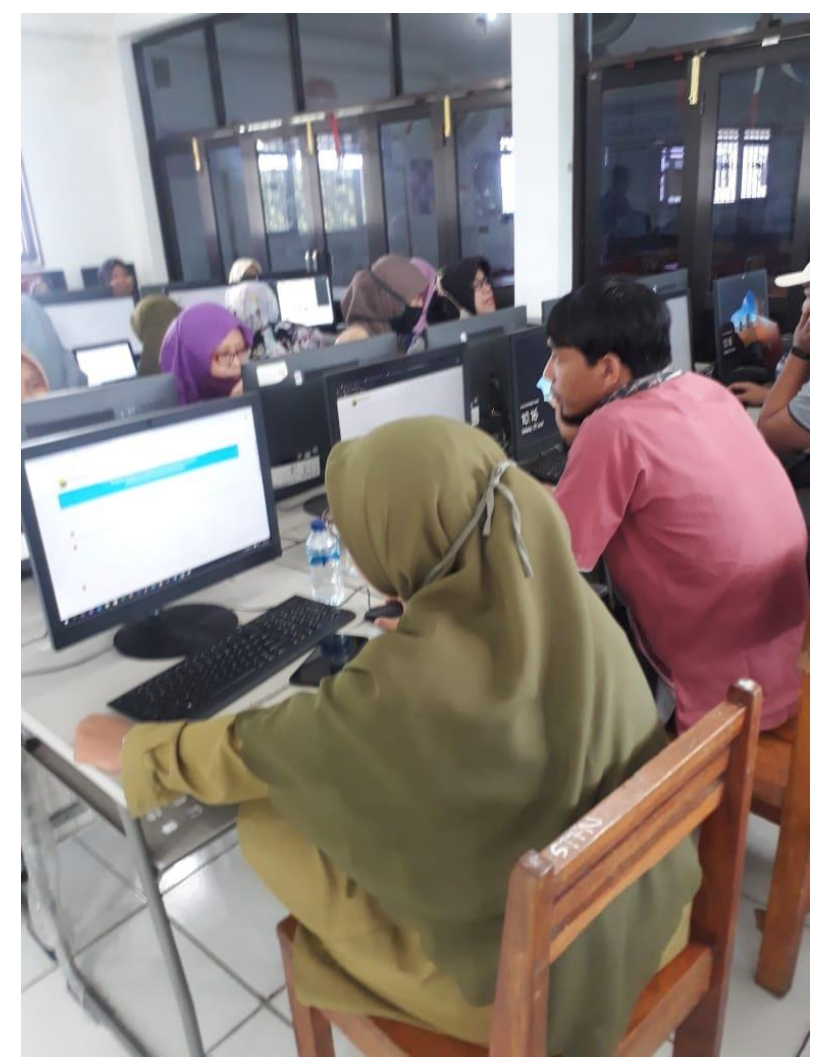

Sumber: Hasil Pelaksanaan (2020)

Gambar 5. Pengisian Kuisioner/Tes Bakat

\subsection{Membaca hasil tes bakat dan diskusi hasil tes personal}

Setelah peserta selesai mengisi semua pertanyaan tes pada aplikasi https://temubakat.com/id/, maka akan muncul hasil/output dari aplikasi terhadap jawaban masing-masing peserta. Hasil tersebut dapat dianalisa dan disimpulkan. Untuk membaca hasil dari tes tersebut, penjelasan dan diskusi dilakukan dipimpin juga oleh pemateri.

Hasil tes bakat yang didapat oleh peserta dari aplikasi temubakat adalah dalam bentuk file pdf. File tersebut dapat di print atau dapat pula dibaca langsung di layar komputer. Hasil tes bakat tiap orang terdiri dari 13 halaman yang berisi gambar(diagram) berwarna dengan kode bakat tertentu, termasuk didalamnya terdapat penjelasan dari kode-kode potensi bakat yang kuat dan yang lemah yang dimiliki peserta yang sudah menyelesaikan tes. Pada halaman pertama adalah gambaran Strength Cluster Map seperti pada gambar 6.

Warna merah menunjukan area potensi kekuatan dominan, warna kuning potensi kekuatan sedang, warna putih potensi netral, warna abu-abu potensi kelemahan sedang, dan warna hitam adalah potensi paling lemah.(Pradani, 2011) Warna-warna tersebut disematkan dalam aktivitas-aktivitas yang dibagi dalam 8 (delapan) Klaster aktivitas, yaitu reasoning, 
Elementary, Networking, Generating Idea, Thinking, Headman, Servicing, dan Technical (Royani, 2016).
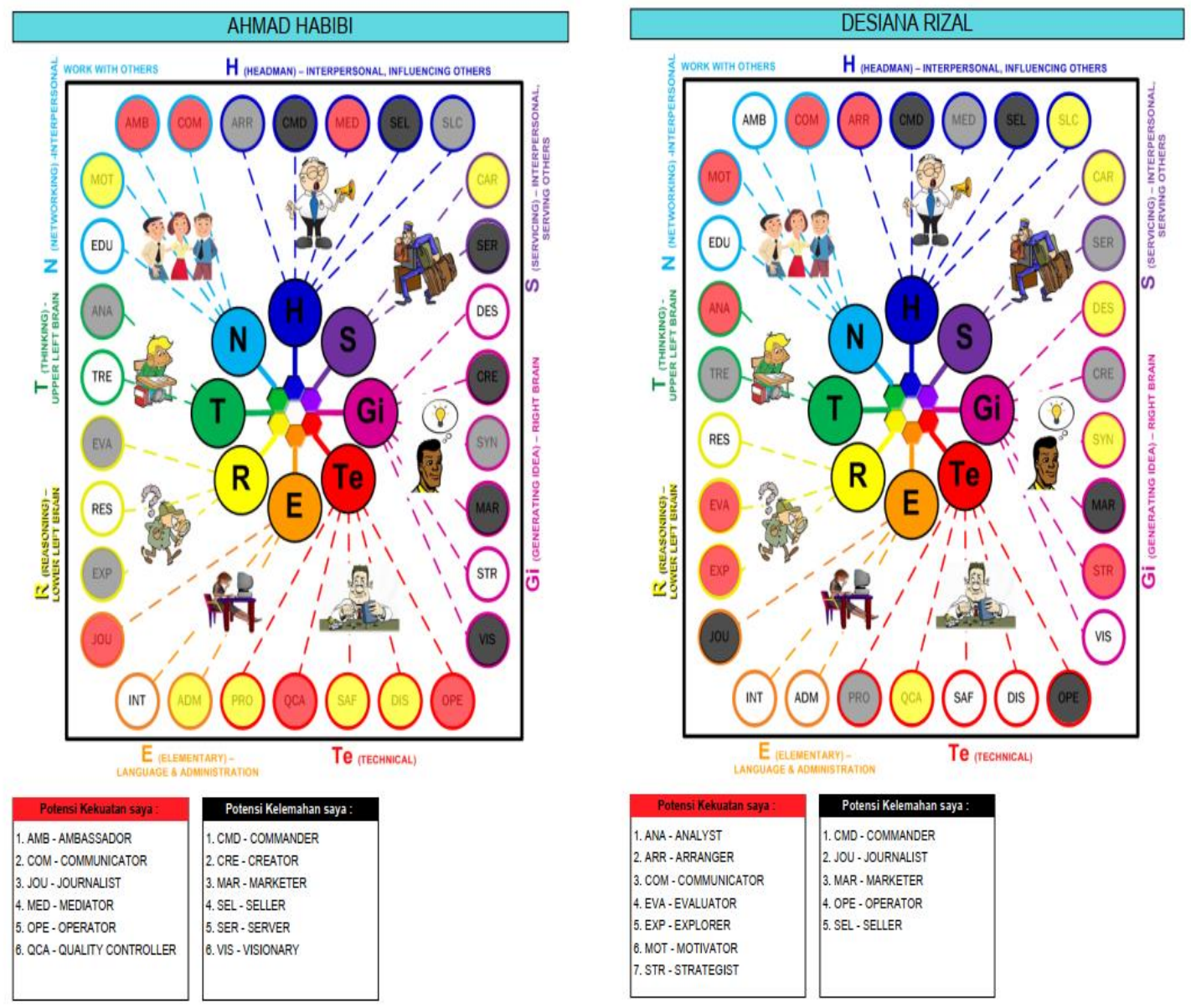

Sumber: Hasil Pelaksanaan (2020)

Gambar 6. Diagram bakat hasil tes ST-30

Setelah setiap orang berusaha membaca dan memahami hasil tesnya sendiri, selanjutnya pemateri memberikan kesempatan kepada peserta untuk mendiskusikan terkait bakat dirinya yang terbaca oleh aplikasi. Teknik membaca bakat dengan memanfaatkan aplikasi Talents Mapping pada situs https://temubakat.com/id/ juga menjadi pembicaraan yang seru yang ditanyakan dan didiskusikan oleh para peserta ke pemateri. Bagi tiga orang peserta yang aktif dan terpilih, pemateri memberikan buku kenang-kenangan terkait "bakat" yang langsung ditulis oleh pemateri. 

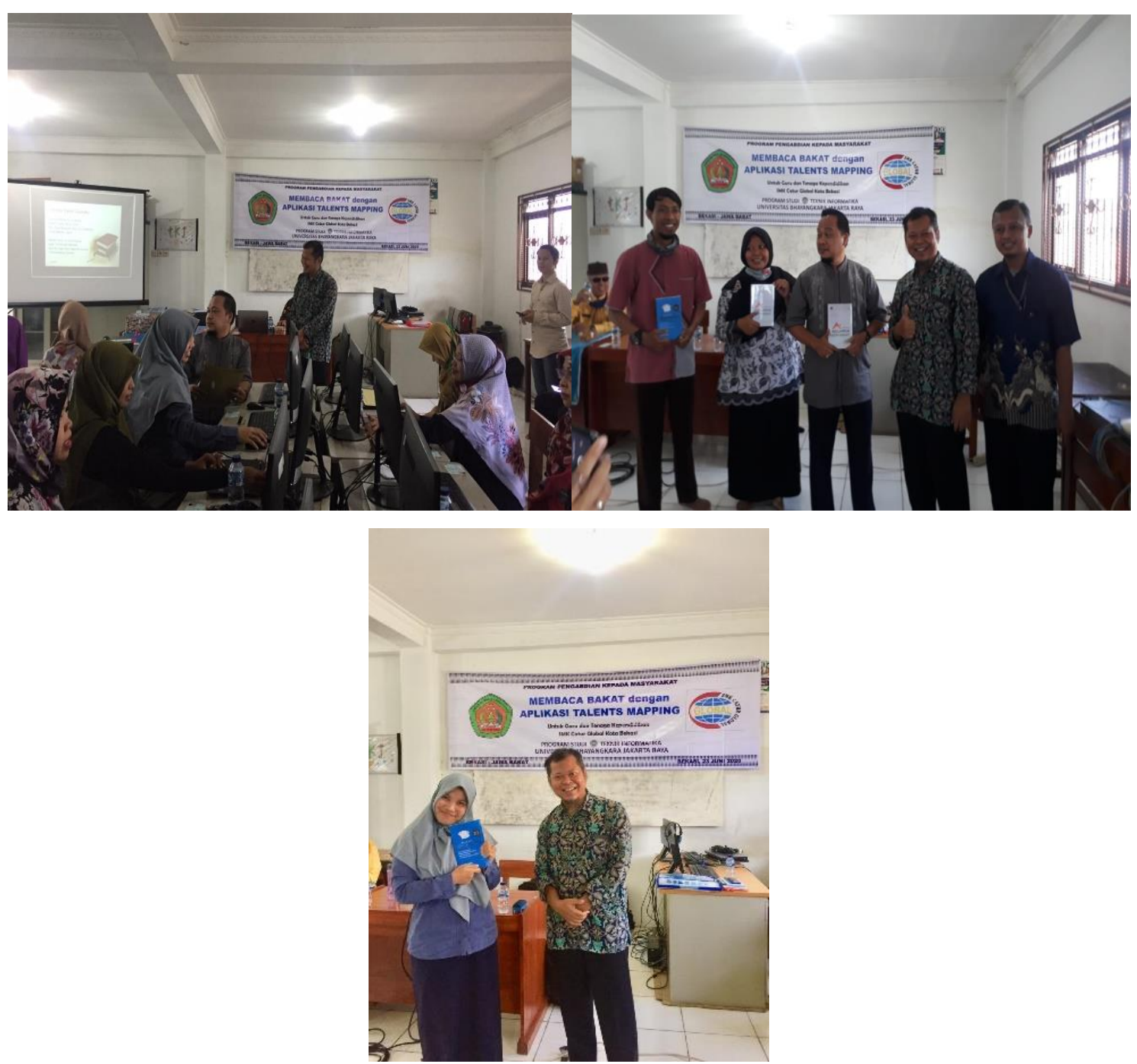

Sumber: Hasil Pelaksanaan (2020)

Gambar 7. Diskusi dan Pemberian Buku Kenang-Kenangan

\subsection{Tes Akhir (Post-test)}

Pada sesi akhir acara pelatihan, peserta diminta untuk mengisi kembali pertanyaan yang sudah disiapkan secara online dalam Googleform. Antusias peserta yang mengisi kuisioner post-test mengalami peningkatan, hal ini terlihat dari jumlah peserta yang bertambah saat mengisi post-test menjadi 19 peserta $(79,17 \%)$, dari jumlah semula yang mengisi kuisioner pre-test sebanyak 16 peserta $(66,67 \%)$. Hal tersebut menunjukan tingkat antusias peserta terhadap pelatihan membaca bakat yang dilakukan mengalami peningkatan sebesar $12,50 \%$ atau sejumlah 3 peserta.

Hasil jawaban peserta dijadikan data bahasan untuk mengevaluasi bagaimana progress pemahaman dan kesan peserta setelah mengikuti pelatihan. Dari kuisioner yang disajikan, didapat data kesesuaian karier yang dijalani peserta selama ini sebagai berikut; 


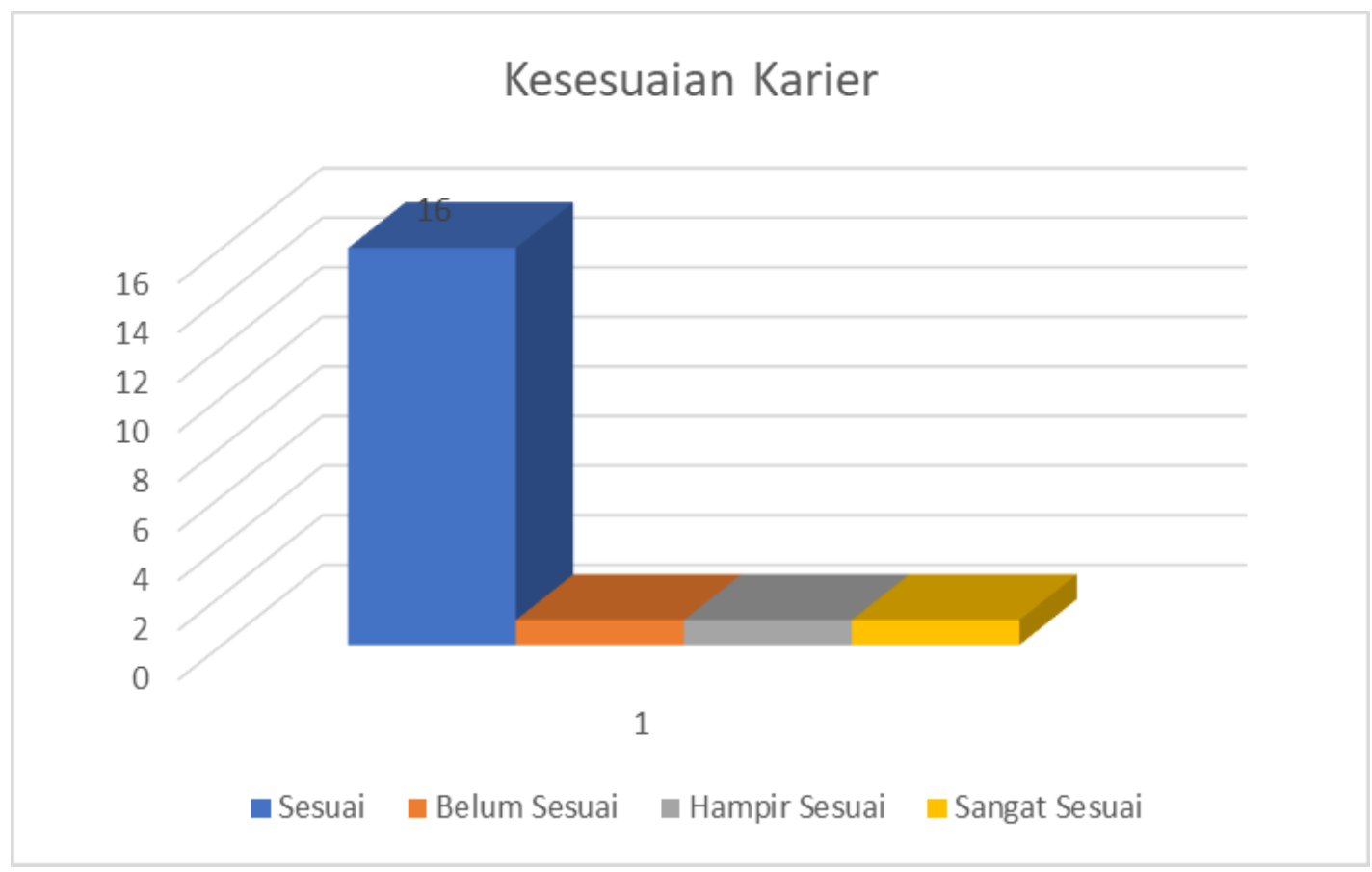

Sumber: Hasil Pelaksanaan (2020)

Gambar 8. Kesesuaian Karier Dan Bakat (Post-Test)

Pada Gambar 8 terlihat bahwa peserta yang menjawab sudah sesuai/cocok antara karier saat ini dengan bakat yang dimilikinya adalah sejumlah 16 peserta atau sekitar $84,21 \%$. Sedangkan yang menjawab Belum sesuai, hamper sesuai, dan sangat sesuai, masing-masing berjumlah 1 orang atau sekitar $5,26 \%$.

\section{Kesimpulan}

Mitra dalam kegiatan pengabdian masyarakat merupakan tenaga pendidik dan kependidikan SMK Catur Global Kota Bekasi. Kegiatan pelatihan membaca bakat ini dilaksanakan untuk memberikan pengetahuan dan pemahaman tambahan terkait bakat da minat untukn mengoptimalkan kesesuaian potensi bakat dengan tugas Pendidikan dan pengajaran yang dilaksanakan. Dalam pelaksanaan kegiatan dilakukan secara luring dimulai dari kegiatan persiapan, penyampaikan materi, proses tes bakat, sampai dengan melakukan diskusi dan pendampingan peserta dalam membaca potensi bakat hasil keluaran aplikasi Talents Mapping ST-30. Dari kegiatan yang dilakukan peserta merasakan manfaat dan ketertarikan terhadap materi yang disampaikan. Hasil penilaian yang diperoleh menunjukkan bahwa peserta merasakan kecocokan antara pekerjaan yang dilakukan saat ini dengan bakat yang dimiliki. Oleh karenanya kegiatan pelatihan membaca bakat dengan aplikasi Tallents Mapping dianggap bermanfaat dan tingkat akurasinya sangat baik. Antusias peserta dalam mengikuti pelatihan Membaca bakat dinilai baik, hal tersebut diukur dari respon peserta dalam pengisian kuisioner akhir (post-test) mencapai $79,17 \%$ dari total peserta yang hadir. 


\section{Ucapan Terima Kasih}

Terima kasih kepada Universitas Bhayangkara Jakarta Raya dan pihak Mitra yaitu SMK Catur Global Kota Bekasi yang telah memberikan dukungan, kesempatan dan meluangkan waktu dalam pelaksanaan kegiatan Pelatihan Membaca Bakat dengan Aplikasi Talents Mapping untuk tenaga pendidik dan kependidikan pada SMK Catur Global Kota Bekasi.

\section{Daftar Pustaka}

Fajria, A. (2019). Talents Observation (S. Patria (ed.); 1st ed.). Tosca Jaya Indonesia.

Fajria, A., \& Dewi, T. S. (2019). Membangun Keluarga Sadar Bakat (S. Patria (ed.); 2nd ed.). Tosca Jaya Indonesia.

Fauzan, A. (2019). Mendorong Mutu Sekolah dengan "Talents Mapping." Kabarkampus.Com. https://kabarkampus.com/2019/10/mendorong-mutu-sekolah-dengan-talents-mapping/

Febrida, M. (2014). Temukan Bakat Terpendam dengan Talents Mapping. Liputan6.Com. https://www.liputan6.com/health/read/2046524/temukan-bakat-terpendam-dengan-talentsmapping

Gubuk Pintar. (2020). Cara Membuat Google Form untuk Kuisioner Survey. Gubukpintar.Com. https://www.gubukpintar.com/2018/06/cara-membuat-google-form.html

Karyaone. (2020). Pengertian Talent Mapping, Manfaatnya dan Langkahnya. Karyaone.Co.Id. https://www.karyaone.co.id/blog/talent-

mapping/\#Pengertian_talents_mapping_pemetaan_bakat

Ningrum, Y., \& Welly, J. (2012). Analysis of Talent Development Influence on Employee Productivity At HR Centre Bandung PT Telekomunikasi Indonesia 2011. Indonesian Journal of Business Administration, 1(1), 28-33.

Pradani, T. S. (2011). Talents Mapping Assesment Result.

Royani, A. R. (2016). Talents Mapping. 47, 104, 106, 107, 130, 131, 166.

TDC Indonesia. (2011). Talents Mapping \& Personal Strength Statement. Indonesiatdc.Wordpress.Com. https://indonesiatdc.wordpress.com/2011/07/03/talentsmapping-personal-strength-statement/ 